\title{
Fixed points for $\alpha-\psi$-Suzuki contractions with applications to integral equations
}

\section{N. Hussain, P. SALimi and P. Vetro}

\begin{abstract}
.
Recently, Suzuki [Proc. Amer. Math. Soc. 136 (2008), 1861-1869] proved a fixed point theorem that is a generalization of the Banach contraction principle and characterized the metric completeness. Paesano and Vetro [Topology Appl., 159 (2012), 911-920] proved an analogous fixed point result on a partial metric space. In this paper we prove some fixed point results for Suzuki- $\alpha-\psi$-contractions and Suzuki- $\varphi_{\theta}-\psi_{r}$-contractions on a complete partially ordered metric space. Moreover, some examples and an application to integral equations are provided to illustrate the usability of the obtained results.
\end{abstract}

Acknowledgement. This article was funded by the Deanship of Scientific Research (DSR), King Abdulaziz University, Jeddah. Therefore, the first author acknowledges with thanks DSR, KAU for financial support. The 3rd author is supported by Università degli Studi di Palermo (Local University Project ex 60\%).

\section{REFERENCES}

[1] Asl, J. H., Rezapour, SH. and Shahzad, N., On fixed point of $\alpha$-contractive multifunctions, Fixed Point Theory Appl., 2012:212 (2012)

[2] Agarwal, R. P., Hussain, N. and Taoudi, M. A., Fixed point theorems in ordered Banach spaces and applications to nonlinear integral equations, Abstr. Appl. Anal., 2012 (2012), Art. ID 245872, 15 pp

[3] Banach, S., Sur les opérations dans les ensembles abstraits et leur application aux équations intégrales, Fund. Math., 3 (1922), 133-181

[4] Berinde, V. and Vetro, F., Common fixed points of mappings satisfying implicit contractive conditions, Fixed Point Theory Appl., 2012:105 (2012), doi:10.1186/1687-1812-2012-105

[5] Boyd, D. W. and Wong, J. S., On nonlinear contractions, Proc. Amer. Math. Soc., 20 (1969), 458-469

[6] Cherichi, M. and Samet, B., Fixed point theorems on ordered gauge spaces with applications to nonlinear integral equations, Fixed Point Theory Appl., 2012:13 (2012)

[7] Ćirić, L., Samet, B., Vetro, C. and Abbas, M., Fixed point results for weak contractive mappings in ordered K-metric spaces, Fixed Point Theory, 13 (2012), 59-72

[8] Ćirić, L., Agarwal, R. P. and Samet, B., Mixed monotone-generalized contractions in partially ordered probabilistic metric spaces, Fixed Point Theory Appl., 2011:56 (2011)

[9] Ćirić, L., Abbas, M., Saadati, R. and Hussain, N., Common fixed points of almost generalized contractive mappings in ordered metric spaces, Appl. Math. Comput., 217 (2011), 5784-5789

[10] Ćirić, L., Hussain, N. and Cakic, N., Common fixed points for Ciric type f-weak contraction with applications, Publ. Math. Debrecen, 76 (2010), 31-49

[11] Golubović, Z., Kadelburg, Z. and Radenović, S., Common fixed points of ordered g-quasicontractions and weak contractions in ordered metric spaces, Fixed Point Theory Appl., 2012:20 (2012)

[12] Hussain, N., Common fixed points in best approximation for Banach operator pairs with Ćirić type I-contractions, J. Math. Anal. Appl., 338 (2008), 1351-1362

Received: 08.03.2013; In revised form: 08.01.2014; Accepted: 15.01.2014

2010 Mathematics Subject Classification. 47H10, 54H25, 55M20.

Key words and phrases. Fixed points, Suzuki- $\alpha-\psi$-contractions, partially ordered metric spaces, integral equations.

Corresponding author: N. Hussain; nhusain@kau.edu.sa 
[13] Hussain, N., Berinde, V. and Shafqat, N., Common fixed point and approximation results for generalized $\phi$ contractions, Fixed Point Theory, 10 (2009), 111-124

[14] Hussain, N., Karapinar, E., Salimi, P. and Akbar, F., $\alpha$-admissible mappings and related fixed point theorems, J. Inequal. Appl., 2013:114 (2013)

[15] Hussain, N., Kutbi, M. A. and Salimi, P., Best proximity point results for modified $\alpha$ - $\psi$-proximal rational contractions, Abstr. Appl. Anal., 2013 (2013), Article ID 927457

[16] Hussain, N., Salimi, P. and Latif, A., Fixed point results for single and set-valued $\alpha-\eta-\psi$-contractive mappings, Fixed Point Theory Appl., 2013:212 (2013)

[17] Hussain, N., Karapinar, E., Salimi, P. and Vetro, P., Fixed point results for $G^{m}$-Meir-Keeler contractive and $G-(\alpha, \psi)$-Meir-Keeler contractive mappings, Fixed Point Theory Appl., 2013:34 (2013)

[18] Hussain, N. and Khamsi, M. A., On asymptotic pointwise contractions in metric spaces, Nonlinear Anal., 71 (2009), 4423-4429

[19] Hussain, N., Khan, A. R. and Agarwal, R. P., Krasnosel'skii and Ky Fan type fixed point theorems in ordered Banach spaces, J. Nonlinear Convex Anal., 11 (2010), No. 3, 475-489

[20] Hussain, N. and Pathak, H. K., Subweakly biased pairs and Jungck contractions with applications, Numer. Funct. Anal. Optimiz., 32 (2011), No. 10, 1067-1082

[21] Hussain, N., Nashine, H. K., Kadelburg, Z. and Alsulami, Saud M., Weakly isotone increasing mappings and endpoints in partially ordered metric spaces, J. Inequal. Appl., 2012:232 (2012)

[22] Hussain, N., Latif, A. and Shafqat, N., Weak contractive inequalities and compatible mixed monotone random operators in ordered metric spaces, J. Inequal. Appl., 2012:257 (2012)

[23] Hussain, N. and Pathak, H. K., Common fixed point and invariant approximation results for H-operator pair with applications, Appl. Math. Comput., 218 (2012), 11217-11225

[24] Jleli, M., Cojbaic' Rajic', V., Samet, B. and Vetro, C., Fixed point theorems on ordered metric spaces and applications to nonlinear elastic beam equations, J. Fixed Point Theory Appl., 12 (2012), 175-192

[25] Karapinar, E., Kumam, P. and Salimi, P., On $\alpha$ - $\psi$-Meir-Keeler contractive mappings, Fixed Point Theory Appl., 2013:94 (2013)

[26] Karapinar, E. and Salimi, P., Fixed point theorems via auxiliary functions, J. Appl. Math., 2012 (2012), Article ID 792174

[27] Khan, A. R. and Akbar, F., Best simultaneous approximations, asymptotically nonexpansive mappings and variational inequalities in Banach spaces, J. Math. Anal. Appl., 354 (2009), 469-477

[28] Matkowski, J., Integrable solutions of functional equations, Dissertationes Math., 127 (1975), 1-68

[29] Matkowski, J., Fixed point theorems for mappings with a contractive iterate at a point, Proc. Amer. Math. Soc., 62 (1977), 344-348

[30] Nieto, J. J. and Rodríguez-López, R., Contractive mapping theorems in partially ordered sets and applications to ordinary differential equations, Order, 22 (2005), 223-239

[31] Paesano, D. and Vetro, P., Suzuki's type characterizations of completeness for partial metric spaces and fixed points for partially ordered metric spaces, Topology Appl., 159 (2012), 911-920

[32] Ran, A. C. M. and Reurings, M. C., A fixed point theorem in partially ordered sets and some applications to matrix equations, Proc. Amer. Math. Soc., 132 (2004), 1435-1443

[33] Salimi, P., Latif, A. and Hussain, N., Modified $\alpha$ - $\psi$-contractive mappings with applications, Fixed Point Theory Appl., 2013:151 (2013)

[34] Salimi, P., Vetro, C. and Vetro, P., Fixed point theorems for twisted $(\alpha, \beta)$ - $\psi$-contractive type mappings and applications, Filomat, 27 (2013), No. 4, 605-615

[35] Salimi, P., Vetro, C. and Vetro, P., Some new fixed point results in non-Archimedean fuzzy metric spaces, Nonlinear Anal. Model. Control, 18 (2013), 344-358

[36] Samet, B., Coupled fixed point theorems for a generalized Meir-Keeler contraction in partially ordered metric spaces, Nonlinear Anal., 72 (2010), 4508-4517

[37] Samet, B. and Vetro, C., An integral version of Ćirić 's fixed point theorem, Mediterr. J. Math., 9 (2012), 225-238

[38] Samet, B., Vetro, C. and Vetro, F., From metric spaces to partial metric spaces, Fixed Point Theory Appl., 2013:5 (2013)

[39] Samet, B., Vetro, C. and Vetro, P., Fixed point theorems for $\alpha$ - $\psi$-contractive type mappings, Nonlinear Anal., 75 (2012), 2154-2165

[40] Suzuki, T., A generalized Banach contraction principle that characterizes metric completeness, Proc. Amer. Math. Soc., 136 (2008), 1861-1869

[41] Turinici, M., Abstract comparison principles and multivariable Gronwall-Bellman inequalities, J. Math. Anal. Appl., 117 (1986), 100-127 
DePARTMENT OF MATHEMATics

KING AbDUlaZIZ UNIVERSITY

P.O. BOX 80203, JEDDAH 21589, SAUdi Arabia

E-mail address: nhusainekau.edu.sa

Young Researchers and Elite Club

RASHT BRANCH, ISLAMIC AZAD UNIVERSITY, RASHT, IRAN

E-mail address: salimipeyman@gmail.com

Dipartimento Di MATEMATICA E INFORMATICA

UNIVERSITÀ DEGLI STUDI DI PALERMO

Via ARChIRAFI, 34 - 90123 PALERMo, ItAly

E-mail address: vetro@math.unipa.it 